Authors' pre-print version (pre-reviewing)

To be published as:

Annemans, A., Heylighen, A., Productive interactions to exchange knowledge in healthcare building design. Building Research and Information

Please refer to the publisher's final version 


\section{Productive interactions to exchange knowledge in healthcare building design}

Margo Annemans \& Ann Heylighen

KU Leuven, Department of Architecture, Research[x]Design

Architects and healthcare organisations involved in designing healthcare environments highly value insights gained through research to inform their practice. Obtaining research funding increasingly presupposes economic and/or societal value of research outcomes. Our study aims to gain a nuanced understanding of what knowledge transfer in an inter- and transdisciplinary context, like healthcare building design, means for various actors involved. Based on the notion of productive interactions, we reflect on a knowledge-transfer project seeking solutions for real-world problems in the design of healthcare buildings with a focus on patient experience. We analyse how different actors involved in the project including researchers, healthcare organisations, and designers- view and value the knowledge provided and transferred, and the (pathways towards) impact. In doing so, we illustrate how productive interactions can take place in real-life situations. We conclude that the roles of researchers and practitioners in knowledge exchange processes should be understood to be fluid. Future realisations of productive interactions could be supported by evaluating knowledge-transfer projects in terms of process and outcomes, thus acknowledging the shifting roles of researchers and practitioners, and the potential to improve well-being and social relations through research.

Keywords: Case study enquiry, Design, Healthcare facilities, Knowledge exchange, Patient experience, Productive interactions, Qualitative research

\section{Introduction}

With the rising number of studies on how the built environment impacts on people's health, the challenge in healthcare building design is no longer a lack of research, but rather deciding which research is most relevant to use, judging its quality and translating it into practice (Sachs, 2018). Moving towards a more 
holistic way of studying healthcare building design and well-being allows to better understand and unravel complexities as they happen in reality (Zhang et al., 2019). To gain insight into this reality, patients, relatives, and staff could be an interesting source of information, yet they are often not heard (Stichler, 2015). Unravelling such a complex reality requires bringing together researchers and practitioners, from heath care and design, to formulate research questions and set up relevant approaches to address them.

Informing healthcare building design requires a combination of inter- and transdisciplinary research type 2 (Sakao \& Brambila-Macias, 2018). Interdisciplinarity refers to a merge of insights from different research areas, c.q. nursing science and building design. Whereas type 1 transdisciplinarity addresses generation of common knowledge beyond research disciplines, type 2 transdisciplinarity focusses on the exchange between research and practice (outside academia), c.q. healthcare and design practice. In architectural practice, the long period from design to realisation makes it challenging to identify the right time for evaluating the impact of a knowledge transfer from research on (building for) health care to a concrete design. When evaluated too soon the impact has yet to happen, the design may not be final yet; when too late actors can recall it only vaguely, once the design process is finished it is hard to trace back when and why design decisions were made (Morton, 2015a).

Also beyond the field of healthcare and architectural practice, the desire for economic and/or societal value of research is recognisable in a growing emphasis on 'impact', 'relevance', or 'valorisation', each with a slightly different connotation depending on the local policy context (van den Akker et al., 2017). 
This desire is confirmed by funding agencies expecting research proposals to include clear statements on (societal) impact and supporting specific programs that focus on knowledge transfer to move forward private parties, both big and small enterprises. How knowledge should be transferred is subject to debate with little concrete examples being published (Pentland et al., 2011). The complexity of the real-world problems in an inter- and transdisciplinary context (Belcher et al., 2016), like healthcare building design, challenges the (successful) realisation of knowledge transfer projects, as such hampering publications about them. Assessing knowledge transfer in a systematic way requires insight into its context, content and approach.

With an eye to assessing the societal impact of knowledge transfer, Spaapen and van Drooge (2011) introduce the concept of 'productive interactions'. An ‘interaction' refers to a contact between researchers and stakeholders (from practice) and is considered 'productive' when these stakeholders apply research results to obtain societal goals (e.g. behaviour change). Interactions can be mediated directly (between people), indirectly (through media, i.e. a research publication or a design), or materially (through financial or other support). The idea behind the concept is that academic knowledge cannot simply be handed over, but is developed in interaction with stakeholders, in a particular context and that impact is the result of a collaborative contribution. The process is thus in the hands of both researchers and stakeholders (van den Akker et al., 2017). Thanks to its explication of real-life situations, empirical evidence of how research outcomes are actually used can improve the understanding of what knowledge transfer could mean and of how impact could be assessed (Lemay \& 
Sa, 2014). In this context, our study aims to gain a nuanced understanding of what knowledge transfer in an inter- and transdisciplinary context, like healthcare building design, means for various actors involved and how the societal impact of such a transfer is being assessed. To this end, we reflect on a knowledge-transfer project, set up to seek solutions for real-world problems in healthcare building design with a focus on patient experience. This focus aligns with the intended societal impact of knowledge transfer in terms of changes in human well-being and social relations between people or organisations (Spaapen \& van Drooge, 2011). Through the analysis of a knowledge-transfer project which was initially not set up to be subject to research, we identify how different actors value the knowledge provision and transfer, and the (pathways towards) impact. Being based on what could be reconstructed after finishing the project, we refer to this analysis as retrospective. With this analysis, we aim to shed light on the viewpoints of various actors involved in knowledge exchange -e.g., researchers, healthcare organisations, architecture firms, the research funding agency- and illustrate how productive interactions can take place in real-life situations.

\section{Literature on knowledge transfer and exchange}

Knowledge exchange, defined as 'a process of generating, sharing, and/or using knowledge through various methods appropriate to the context, purpose, and participants involved' (Fazey et al., 2013), is increasingly recognised as a research field in its own right (Straus et al., 2011). Given the close interrelation between how knowledge is conceptualised, produced, and evaluated, research in this field points at the role of evaluation methodologies in how different voices are heard (Fazey et al., 2014). Literature reviews on knowledge transfer and exchange and 
the related impact abound, even if one considers only those in the field of health care. Some of these focus on the quality of the knowledge exchanged (Belcher et al., 2016), others on the process of transferring and exchanging knowledge (Pentland et al., 2011), and yet others on research impact and its assessment (Cruz Rivera et al., 2017; Penfield et al., 2014).

Valued knowledge is scientifically robust and socially relevant (Spaapen \& van Drooge, 2011). One way to guarantee this robustness is starting from evidence. As mentioned, the growing amount of research on health effects of the built environment raises questions regarding how to judge its quality and translate it into practice (Sachs, 2018). In the (similar) context of policy supporting research, Kampen and Tamas (2014) propose a simple checklist to help decide whether a piece of research is worth considering. This decision is based on the provided knowledge and the applied research approach.

How healthcare professionals value the provided knowledge depends on how it is presented, and which methods are used to share it. A literature review on knowledge exchange in health care concluded that there is a need for (1) a change in researchers' and healthcare professionals' roles to allow greater involvement of the latter in the process of knowledge exchange, (2) active support and according funding to ensure suitable conditions for knowledge exchange, and (3) further research into methods and techniques for this exchange (Pentland et al., 2011). In the context of design, it is argued that research struggles to offer the knowledge designers need. The importance is stressed of context-dependent knowledge, embedded in examples and linked to experience (Kirkeby, 2009) 
The interaction between the actors involved in knowledge exchange (referred to above as stakeholders) is more complex than suggested by the overly simplified two-way relationship between researcher and research user. Insight into the multiplicity and specificity of these actors is essential to better understand the role of the research user's agency in research use (Lemay \& Sa, 2014). When studies are set up in a healthcare context, close collaboration between researchers and healthcare professionals is identified as important for the resulting knowledge to be more relevant and practicable (Pentland et al., 2011). In the context of healthcare building design an additional group of stakeholders are built environment professionals. Close collaboration between researchers and research users does not guarantee actual knowledge exchange, however. It is only the start of a process in which research uptake and use are still steps removed from actual impact creation (Morton, 2015a).

Research impact is not static: over time it can develop and change, increase or decrease (Penfield et al., 2014). Whereas identifying primary use of research outcomes is already difficult, anticipating potential secondary use is hardly possible (Upton et al., 2014). How knowledge transfer becomes relevant in different policy and practice settings is unpredictable (Morton, 2015a). This poses a challenge for researchers and funding agencies, yet confirms the importance of paying attention to the knowledge exchange process -and the groups of actors that are being reached along the way- and not only to the outcome (Cruz Rivera e.a., 2017). 


\section{Material and Methods}

\section{Case study}

The case under study is a project funded by a funding program aiming to linearly transfer technology from research to practice in order to initiate a rise in investments, profit, and employment in the local region. The funding agency's aim with this program is not to generate new knowledge, but to transfer existing knowledge from completed research projects to concrete applications by providing suitable information (omitted for blind review). An important requirement in the application procedure was the establishment of a user-group that would meet every 6 months to guard the project's relevance for practice and the (financial) engagement of business partners for $10 \%$ of the project cost. Additionally, the funding agency demanded a link with the teaching curriculum and the organisation of public events to reach a broader audience. In order to facilitate the impact assessment, the requirements were expected to be translated to numerical key performance indicators (KPI's).

In complex and hard-to-enter healthcare settings, designers have difficulty to collect information about patients' experience and healthcare organisations experience difficulties to approach their familiar environment from a patient perspective. Starting from this observation, we submitted an application for a knowledge-transfer project which aimed to explore how insight into patient experience, resulting from research in healthcare contexts, could be applied in healthcare and design practice in order to support the development of spaces that improve patient experience. 


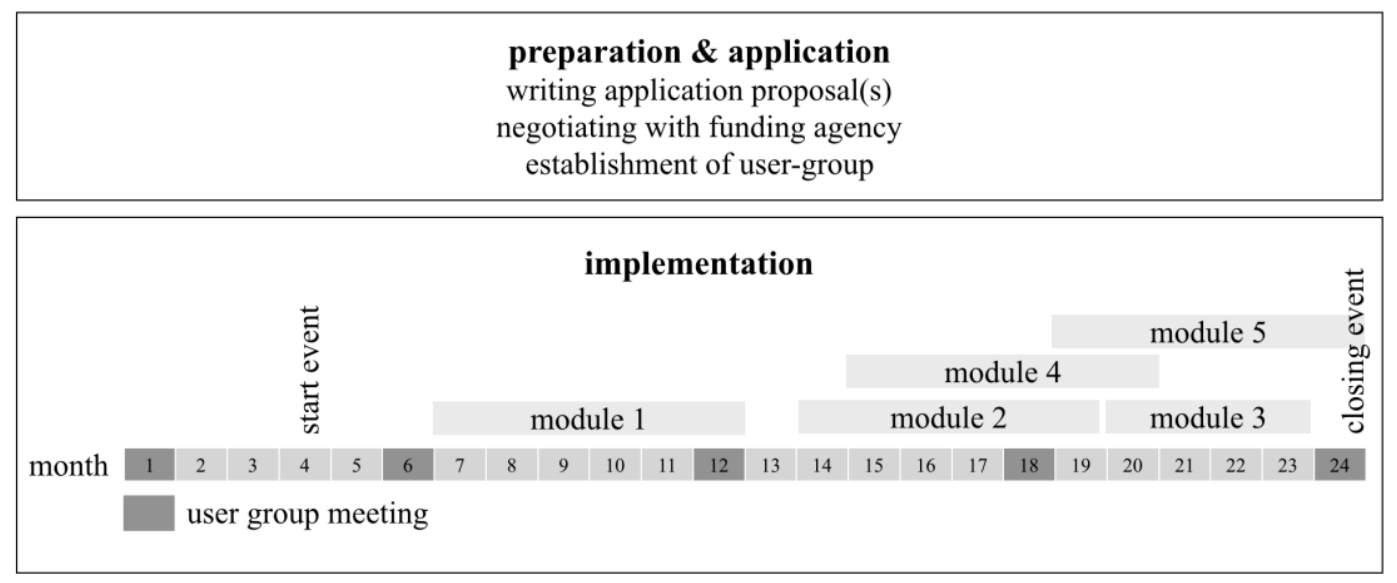

Figure 1. Project outline

Apart from some public events at the start and end of the project period, the body of the project consisted of collaborations with healthcare organisations concerning their current or future (designed) environment, or with architecture firms concerning a particular design process. Each of these collaborations aimed to answer a concrete question related to patient experience (see Table 1). We refer to these collaborations as interactive modules. The organisations and firms engaged in the modules were all part of the user-group established in the application phase and contributed financially to the project. In line with the funding program's aim, they are all based - and all modules were set up - locally. For each participating organisation or firm, the respective module was tailored to a specific request and addressed an actual substantive or methodological question. Together the five show a broad spectrum of exchange processes and outcomes.

\begin{tabular}{|c|c|c|c|}
\hline Module. & Aim / initiator / patient profile & Interactions & Involved \\
\hline \multirow[t]{2}{*}{$\begin{array}{l}\text { Wayfinding } \\
\text { (M1) }\end{array}$} & \multirow{2}{*}{$\begin{array}{l}\text { To improve wayfinding in a general } \\
\text { hospital by analysing the existing } \\
\text { situation and developing strategies to } \\
\text { solve certain problems based on } \\
\text { enhanced understanding of patients' } \\
\text { experience and theoretical concepts } \\
\text { of wayfinding. }\end{array}$} & Initial meeting & $\begin{array}{l}\text { Authors presenting the aim of the overarching project } \\
\left(1^{\text {st }}\right) \text { and facilitating the discussing on possible topics } \\
\text { for the module (both) } \\
\text { Facility manager }\end{array}$ \\
\hline & & 3 workshops & $\begin{array}{l}\text { First author organising workshop, researcher assisting } \\
\text { with organisation of workshop, researcher providing } \\
\text { technical support } \\
\text { Facility manager, head and employee of the building } \\
\text { department, employee of the prevention service, } \\
\text { patient administration processes manager, employee } \\
\text { patient administration processes (= reception staff), }\end{array}$ \\
\hline
\end{tabular}




\begin{tabular}{|c|c|c|c|}
\hline & $\begin{array}{l}\text { entrance are considered } \\
\text { representative }\end{array}$ & & $\begin{array}{l}\text { employee patient transport, employee logistics, } \\
\text { security staff, reception volunteer, nurse }\end{array}$ \\
\hline & & Email conversation & $\begin{array}{l}\text { First author managing the module } \\
\text { Facility manager }\end{array}$ \\
\hline \multirow[t]{4}{*}{$\begin{array}{l}\text { Waiting } \\
\text { (M2) }\end{array}$} & \multirow{4}{*}{$\begin{array}{l}\text { To offer insight into how technological } \\
\text { devices could be used to inform } \\
\text { patients during waiting in an } \\
\text { ambulatory centre and how this } \\
\text { would impact on their waiting } \\
\text { experience } \\
\text { Initiator: academic hospital } \\
\text { Patient profile: Former patients of the } \\
\text { academic hospital, with specific } \\
\text { attention to diversity regarding } \\
\text { abilities (different age groups, visual } \\
\text { or auditive impaired, people with } \\
\text { autism, wheelchair users) }\end{array}$} & Initial meeting & $\begin{array}{l}\text { Authors - idem initial meeting M1 } \\
\text { Head of spatial planning and employee patient } \\
\text { satisfaction } \\
\text { Head of working group "Patient tracking" }\end{array}$ \\
\hline & & $\begin{array}{l}\text { Meeting with working } \\
\text { group (aim \& } \\
\text { approach) }\end{array}$ & $\begin{array}{l}\text { Authors discussing the approach of the workshops } \\
\text { Members working group "Patient tracking" }\end{array}$ \\
\hline & & $\begin{array}{l}3 \text { workshops with } \\
\text { former patients }\end{array}$ & $\begin{array}{l}\text { First author organising the workshops, researcher } \\
\text { assisting with organisation of workshop, researcher } \\
\text { providing technical support } \\
3 \times 8 \text { former patients with various abilities }\end{array}$ \\
\hline & & $\begin{array}{l}\text { Presentation to } \\
\text { working group } \\
\text { (outcomes) }\end{array}$ & $\begin{array}{l}\text { Authors presenting the outcomes of the workshops } \\
\left(1^{\text {st }}\right) \text { answering questions from the working group } \\
\text { (both) } \\
\text { Members working group "Patient tracking" } \\
\text { Employee patient satisfaction }\end{array}$ \\
\hline \multirow[t]{5}{*}{$\begin{array}{l}\text { Palliative } \\
\text { care (M3) }\end{array}$} & \multirow{5}{*}{$\begin{array}{l}\text { To identify spatial characteristics } \\
\text { relevant for guests', relatives', and } \\
\text { staffs' experience in order to be able } \\
\text { to better inform design of a new } \\
\text { palliative care centre and steer and } \\
\text { assess the presented plans. } \\
\frac{\text { Initiator: palliative care centre }}{\text { Patient profile: palliative patients, }} \\
\text { both in-patients in final stage of life } \\
\text { and ambulatory ones. }\end{array}$} & Initial meeting & $\begin{array}{l}\text { Authors - idem initial meeting M1 } \\
\text { Head of the board of the palliative care organisation, } \\
\text { coordinator new building, care coordinator, } \\
\text { Head of architecture firm, architect }\end{array}$ \\
\hline & & $\begin{array}{l}\text { Fieldwork: multiple } \\
\text { days of observations } \\
\text { and (focus group) } \\
\text { interviews }\end{array}$ & $\begin{array}{l}\text { First author conducting and organising fieldwork, } \\
\text { researcher co-conducting and organising fieldwork } \\
\text { Guests, relatives, staff, volunteers }\end{array}$ \\
\hline & & Presentation & $\begin{array}{l}\text { Authors presenting }\left(1^{\text {st }}\right) \text {, facilitating discussion (both) } \\
\text { Head of the board of the palliative care organisation, } \\
\text { coordinator new building, care coordinator }\end{array}$ \\
\hline & & Final presentation & $\begin{array}{l}\text { Last author - answering questions, researcher co- } \\
\text { conducting and organising and presenting (outcomes } \\
\text { of) fieldwork } \\
\text { Head of the board of the palliative care organisation, } \\
\text { coordinator new building, care coordinator, voluntary } \\
\text { attendance of staff and volunteers }\end{array}$ \\
\hline & & Meeting & $\begin{array}{l}\text { First author presenting of the outcomes of project, } \\
\text { answering questions } \\
\text { Partner of architecture firm }\end{array}$ \\
\hline \multirow[t]{4}{*}{$\begin{array}{l}\text { Literature } \\
\text { (M4) }\end{array}$} & \multirow[t]{4}{*}{$\begin{array}{l}\text { To provide an architecture firm with a } \\
\text { framework to collect, analyse, and } \\
\text { evaluate literature in terms of the } \\
\text { trustworthiness of the content and } \\
\text { the relevance for architectural design. }\end{array}$} & Initial meeting & $\begin{array}{l}\text { First author presenting the aim of the overarching } \\
\text { project and facilitating the discussing on possible } \\
\text { topics for the module } \\
\text { Partner of the architecture firm, junior architect }\end{array}$ \\
\hline & & Presenting approach & $\begin{array}{l}\text { First author presenting and discussing approach } \\
\text { Partner of the firm, junior architect }\end{array}$ \\
\hline & & $\begin{array}{l}\text { Discussing } \\
\text { adaptations }\end{array}$ & $\begin{array}{l}\text { First author presenting and discussing adaptations } \\
\text { Partner of the firm, junior architect }\end{array}$ \\
\hline & & $\begin{array}{l}\text { Final presentation \& } \\
\text { evaluation }\end{array}$ & $\begin{array}{l}\text { First author presenting final framework and answering } \\
\text { questions } \\
\text { Partner of the firm, junior architect }\end{array}$ \\
\hline \multirow[t]{3}{*}{ SBD (M5) } & \multirow{3}{*}{$\begin{array}{l}\text { To introduce a design team to } \\
\text { scenario-based design (SBD) - a family } \\
\text { of flexible techniques (persona's and } \\
\text { scenario's) for exploring user } \\
\text { experience during design explicitly } \\
\text { and iteratively - in order to explore its } \\
\text { potential for architectural design. } \\
\text { Initiator: architecture firm (in dialogue } \\
\text { with client) } \\
\text { Patient profile: residents of residential } \\
\text { care home (+ visitors and staff } \\
\text { members) }\end{array}$} & Initial meeting & $\begin{array}{l}\text { Authors idem initial meeting M1, researcher } \\
\text { developing SBD approach } \\
\text { Senior architect }\end{array}$ \\
\hline & & 3 workshops & $\begin{array}{l}\text { First author organising and co-conducting workshops, } \\
\text { researcher developing SBD approach and conducting } \\
\text { workshops } \\
\text { Partner at the firm, Communication manager, senior } \\
\text { architect responsible for care projects, } 4 \text { members of } \\
\text { the project team (architects and interior architect) } \\
\text { Client }\end{array}$ \\
\hline & & $\begin{array}{l}\text { Evaluation at } \\
\text { architecture firm (part } \\
A \& B \text { ) }\end{array}$ & $\begin{array}{l}\text { Authors facilitating discussion, researcher developing } \\
\text { SBD approach } \\
\text { Part A: Partner at the firm, Communication manager, } \\
\text { senior architect responsible for care projects } \\
\text { Part B: Project team }\end{array}$ \\
\hline
\end{tabular}




\begin{tabular}{|l|l|l|l|}
\hline & Evaluation with client & $\begin{array}{l}\text { First author facilitating discussion, researcher } \\
\text { developing SBD approach } \\
\text { Client }\end{array}$ \\
\hline
\end{tabular}

\section{Table 1. Overview of modules}

During the preparation phase, we discussed the initial idea for the project with a representative of the funding agency. We agreed to investigate how an online platform could work as a mediator to communicate the outcomes of the modules to make knowledge on patient experience broadly accessible for healthcare and design professionals. The resulting online platform can be consulted here (link omitted for blind review).

\section{Data collection and analysis}

Analysing the knowledge transfer was not the intent during the project. Therefore, the evidence was collected only after the project was completed, distilled from various documents (notes, reports, ...) as presented in Table 2.

\begin{tabular}{|c|c|c|}
\hline & Interactions & Analysed data \\
\hline \multirow[t]{2}{*}{ Preparation } & Application & $\begin{array}{l}\text { Website of the funding agency } \\
\text { Notes from discussion with representative of the funding } \\
\text { agency } \\
\text { Application form } \\
\text { Revised application form }\end{array}$ \\
\hline & Starting event & $\begin{array}{l}\text { Presentations } \\
\text { Reflections of participants on white board papers }\end{array}$ \\
\hline \multirow[t]{3}{*}{$\begin{array}{l}\text { M1. } \\
\text { Wayfinding }\end{array}$} & Initial meeting & $\begin{array}{l}\text { notes authors } \\
\text { meeting report }\end{array}$ \\
\hline & 3 workshops & $\begin{array}{l}\text { Provided information through online platform } \\
\text { Notes author } 1 \\
\text { End report }\end{array}$ \\
\hline & Email conversation & email \\
\hline \multirow[t]{4}{*}{$\begin{array}{l}\text { M2. } \\
\text { Waiting }\end{array}$} & Initial meeting & $\begin{array}{l}\text { notes of both authors } \\
\text { meeting report }\end{array}$ \\
\hline & $\begin{array}{l}\text { Meeting with working } \\
\text { group (aim \& approach) }\end{array}$ & notes both authors \\
\hline & $\begin{array}{l}3 \text { workshops with former } \\
\text { patients }\end{array}$ & $\begin{array}{l}\text { notes author } 1 \\
\text { email reports quality manager }\end{array}$ \\
\hline & $\begin{array}{l}\text { Presentation to working } \\
\text { group (outcomes) }\end{array}$ & $\begin{array}{l}\text { notes authors } \\
\text { presentation with findings and conclusion of the workshops }\end{array}$ \\
\hline \multirow{4}{*}{$\begin{array}{l}\text { M3. } \\
\text { Palliative } \\
\text { care }\end{array}$} & Initial meeting & $\begin{array}{l}\text { notes of both authors } \\
\text { meeting report }\end{array}$ \\
\hline & $\begin{array}{l}\text { Intermediate } \\
\text { presentation }\end{array}$ & $\begin{array}{l}\text { notes authors } \\
\text { presentation }\end{array}$ \\
\hline & Final presentation & $\begin{array}{l}\text { Notes author } 2 \\
\text { Presentation on findings and conclusions of the fieldwork }\end{array}$ \\
\hline & Meeting with architect & notes author 1 \\
\hline
\end{tabular}




\begin{tabular}{|c|c|c|}
\hline \multirow[t]{4}{*}{$\begin{array}{l}\text { M4. } \\
\text { Literature }\end{array}$} & Initial meeting & $\begin{array}{l}\text { notes author } 1 \\
\text { meeting report }\end{array}$ \\
\hline & Presenting approach & $\begin{array}{l}\text { notes author } 1 \\
\text { slides presentation } \\
\text { document with evaluation grid }\end{array}$ \\
\hline & Discussing adaptations & $\begin{array}{l}\text { notes author } 1 \\
\text { adapted document evaluation grid }\end{array}$ \\
\hline & $\begin{array}{l}\text { Final presentation \& } \\
\text { evaluation }\end{array}$ & $\begin{array}{l}\text { notes author } 1 \\
\text { final version evaluation grid }\end{array}$ \\
\hline \multirow[t]{4}{*}{$\begin{array}{l}\text { M5. } \\
\text { SBD }\end{array}$} & Initial meeting & $\begin{array}{l}\text { notes of both authors } \\
\text { meeting report }\end{array}$ \\
\hline & 3 workshops & 1 \\
\hline & $\begin{array}{l}\text { Evaluation at } \\
\text { architecture firm }\end{array}$ & Notes authors \\
\hline & Evaluation with client & notes author 1 \\
\hline \multirow[t]{2}{*}{ Aftermath } & $\begin{array}{l}\text { Meeting with } \\
\text { governmental } \\
\text { organisations }\end{array}$ & $\begin{array}{l}\text { Notes author } 1 \\
\text { Emails on content and layout of webpages }\end{array}$ \\
\hline & Closing event & Presentations \\
\hline $\begin{array}{l}\text { Throughout } \\
\text { the project }\end{array}$ & User-group meetings & $\begin{array}{l}\text { Notes author } 1 \\
\text { Meeting reports }\end{array}$ \\
\hline
\end{tabular}

Table 2. Overview of analysed documents

These documents were thematically analysed, supplementing theory-driven codes stemming from previous research with data-driven codes constructed throughout the process (Fereday \& Muir-Cochrane, 2006). In order to gain a better understanding of what knowledge transfer and impact means for various actors, we focused on what knowledge healthcare organisations and architecture firms aim for, how the knowledge transfer took place, and what happened afterwards. To this end, we analysed what the participating healthcare organisations and architecture firms expected as outcomes of the interactions, what we were able to offer them, and what they actually got out of the interactions. Additionally, we looked at how the user-group perceived the project and how they suggested to approach the project and its outreach.

\section{Ethics}

All participants in the modules were informed about the intent of the project. They were asked permission for audio-recordings and other information collected during the modules to be used by the researchers for future research. 
When the modules made use of ethically sensitive research outcomes, as was the case for module $1,2,4$, and 5, these resulted from research projects where participants had been explicitly given permission to use the collected material in future projects. For module 3 and 5 we obtained approval from the university's ethical committee.

\section{Reflexivity}

Both authors were involved in writing the project application, discussing the preliminary idea with a representative of the funding agency, and defending the project application for a jury. As coordinator of the project the first author organized and participated in all exchange moments with healthcare organisations and designers. For each module other researchers were involved during the preparation and implementation. The second author supervised the project and was mainly involved during the initial contacts, the events and the user-group meetings.

Although we always presented ourselves as researchers, our role differed significantly between and throughout the modules depending on the phase and the counterparty. Some participants considered us experts/consultants, others, codesigners, and sometimes, especially when working with patients, we took the role of voluntary caregiver.

Our close involvement in the knowledge-transfer project could be considered a limitation as it undoubtedly brings a bias in the analysis. On the other hand, as our analysis aims to reflect on - rather than evaluate - the project, this involvement allowed us to bring to the fore implicit outcomes of the interactions between 
researchers and participants, which would otherwise have been overlooked as they are not explicitly documented.

\section{Limitations}

Our study shows limitations of various origins: the divergence between the modules, the narrow geographical scope, and the limited information we could obtain about the modules' long(er)-term impact.

How the knowledge-transfer project was set up, was inspired by the practiceoriented aim of the funding program. This resulted in divergent modules, in terms of content (e.g. topic and patient profiles) and approach, which sometimes complicated the analysis. Yet, it is exactly this divergence within one project that allowed to identify similarities and differences between otherwise hard to compare situations. Despite their overarching aim to bring knowledge on patient experience to the practice of healthcare building design, the modules illustrate how knowledge transfer in collaboration with practitioners, can develop in unanticipated ways (Morton, 2015b) regardless of how the transfer was planned in advance.

The funding agency stresses the added value of the granted funding for the local region. This resulted in a user-group composed of healthcare organisations and architecture firms based in <region omitted for blind review>. This might hamper the generalisability of the finding to other regions. Due to the module-based approach the local embedding is an inherent part of the adopted approach. Despite all efforts, assessing the effects of knowledge exchange is hardly possible (Pentland et al., 2011). Researchers are not always informed about what comes forth from the interaction. In one module (M1), the researchers were asked to 
participate in a follow-up project, a clear indication that the topic was still on the agenda, yet when the follow-up project was postponed, all information channels on what is happening were cut off. The construction of the new palliative centre (M3) has just started, leaving at least another year before the researchers are able to go back to study the new building. This difference in pace hampers a crossmodule impact assessment of interventions in the design process (Penfield et al., 2014).

\section{Findings}

In order to identify what knowledge transfer means for various actors involved, we first shed a light on what the participating healthcare organisations and architecture firms expected to gain from their participation in the project, followed by what the researchers (were able to) offer them. Finally, we elaborate on the impact of the interactions.

\begin{tabular}{|c|c|c|c|}
\hline & Expected outcome & What is offered & Impact \\
\hline $\begin{array}{l}\text { By funding } \\
\text { agency }\end{array}$ & $\begin{array}{l}\text { - Financial involvement of } \\
\text { industry partners } \\
-\quad \text { Reaching KPI's regarding } \\
\text { numbers of healthcare organisations } \\
\text { and design firms involved, of } \\
\text { organisations, firms, and students } \\
\text { reached, and of collaborations } \\
\text { initiated. } \\
-\quad \text { Extending the project's } \\
\text { impact beyond the participating } \\
\text { organisations. } \\
-\quad \text { Making the insights } \\
\text { gained through the development of } \\
\text { the project accessible to and useable } \\
\text { by a wider audience. }\end{array}$ & $\begin{array}{l}\text { - Application according to } \\
\text { expectations } \\
\text { A platform to share, in a } \\
\text { design-oriented manner, insight into } \\
\text { how the built environment impacts on } \\
\text { people's well-being (hosted on the } \\
\text { website of the regional government } \\
\text { agency). The platform offers: } \\
\text { a presentation of the research } \\
\text { context, concrete outcomes of } \\
\text { each module and contact details } \\
\text { of initiator and research team, } \\
\text { the diversity in substantive and } \\
\text { methodological information } \\
\text { An infographic explicating the } \\
\text { relevance of insight into patient } \\
\text { experience throughout the design } \\
\text { process, focussing on the added } \\
\text { value for interaction between } \\
\text { clients (i.e., healthcare } \\
\text { organisations), architects, and } \\
\text { researchers. } \\
\text { A first version of the platform was } \\
\text { presented at the project's closing event. } \\
\text { At this moment a call was launched for } \\
\text { more exemplary healthcare building }\end{array}$ & $\begin{array}{l}\text { Reaching a broader audience } \\
\text { than by hosting the information } \\
\text { locally. }\end{array}$ \\
\hline
\end{tabular}




\begin{tabular}{|c|c|c|c|}
\hline & & $\begin{array}{l}\text { design projects to be added on the } \\
\text { website. }\end{array}$ & \\
\hline $\begin{array}{l}\text { In M1. } \\
\text { Wayfinding }\end{array}$ & $\begin{array}{l}\text { - Concrete solution for the } \\
\text { occurring wayfinding problems. }\end{array}$ & $\begin{array}{l}\text { - Approach to consider the } \\
\text { hospital building and wayfinding system } \\
\text { from different perspectives. This } \\
\text { resulted in a better understanding of } \\
\text { the specificities of patients' experience } \\
\text { - being nervous, unfamiliar with the } \\
\text { building and the signage } \\
\text { - Insight into wayfinding } \\
\text { issues based on theoretical concepts, } \\
\text { patients' testimonies about how they } \\
\text { experienced wayfinding, and photo and } \\
\text { video material from a previous project } \\
\text { showing patients moving through a } \\
\text { hospital (Annemans et al., 2017b) } \\
\text { - Approach to engage with } \\
\text { this insight to analyse the existing } \\
\text { situation and develop strategies to } \\
\text { solve occurring problems based on their } \\
\text { enhanced understanding of patients' } \\
\text { experience. }\end{array}$ & $\begin{array}{l}\text { - initiation of a novel } \\
\text { thread of thought about diverse } \\
\text { user-perspectives, not only } \\
\text { regarding patients but also } \\
\text { resulted in staff gaining a better } \\
\text { understanding of how their } \\
\text { experience of daily practices } \\
\text { could diverge from the one of } \\
\text { their colleagues. This resulted in } \\
\text { a better understanding and more } \\
\text { free communication amongst } \\
\text { them and added to the success } \\
\text { of the later workshop sessions } \\
\text { - investment of } € \\
20.000 \text { in new signage } \\
\text { - a new wayfinding } \\
\text { system developed by one of the } \\
\text { participants }\end{array}$ \\
\hline $\begin{array}{l}\text { In M2. } \\
\text { Waiting }\end{array}$ & $\begin{array}{l}\text { - Concrete spatial solution } \\
\text { for the organisation of the waiting } \\
\text { area of a new ambulatory centre }\end{array}$ & $\begin{array}{l}\text { - Theoretical framework } \\
\text { based on literature review } \\
\text { - Insight into waiting } \\
\text { experience based on workshops with } \\
\text { former patients asked to act out } \\
\text { different waiting scenarios while being } \\
\text { informed through mock-ups of different } \\
\text { devices. This hands-on activity was } \\
\text { organised in the presence of a staff } \\
\text { member responsible for patient quality } \\
\text { and later discussed with the } \\
\text { participants. } \\
\text { - Themes to be considered in } \\
\text { when designing the ambulatory centre }\end{array}$ & $\begin{array}{l}\text { - lessons learned about } \\
\text { the way of working and } \\
\text { interacting in the ambulatory } \\
\text { centre. As a workshop } \\
\text { participant stated "it can also be } \\
\text { a way of questioning your own } \\
\text { organisation." }\end{array}$ \\
\hline $\begin{array}{l}\text { In M3. } \\
\text { Palliative care }\end{array}$ & $\begin{array}{l}\text { - Knowledge to guide the } \\
\text { organisation in answering concrete } \\
\text { design questions from the architects }\end{array}$ & $\begin{array}{l}\text { - Insight into the impact of } \\
\text { space on the atmosphere in the centre } \\
\text { based on interviews with patients, staff, } \\
\text { and relatives } \\
\text { - Design themes for the new } \\
\text { building }\end{array}$ & $\begin{array}{l}\text { - Insights used by } \\
\text { organisation as a guide for } \\
\text { discussions with architect } \\
\text { - raised awareness } \\
\text { about, and willingness to } \\
\text { reconsider, the figurative wall } \\
\text { between two parts of the } \\
\text { organisation by bringing together } \\
\text { people with similar profiles } \\
\text { working in the different parts. } \\
\text { - request for the } \\
\text { researchers to be permanently } \\
\text { involved throughout the design } \\
\text { process of the new building, } \\
\text { which was not feasible. } \\
\text { - Follow-up project in } \\
\text { new building (starting spring } \\
\text { 2020) in which the outcomes of } \\
\text { the conducted study will be used } \\
\text { to assess the new building and - } \\
\text { when needed - further attune } \\
\text { building and organisation. }\end{array}$ \\
\hline $\begin{array}{l}\text { In M4. } \\
\text { Literature }\end{array}$ & $\begin{array}{l}\text { - Method to document and } \\
\text { communicate insights on hospital } \\
\text { design (including patient experience) } \\
\text { from various sources }\end{array}$ & $\begin{array}{l}\text { - a tool that visually } \\
\text { communicates to fellow workers both } \\
\text { the relevance for architectural design } \\
\text { and the scientific robustness of } \\
\text { literature. }\end{array}$ & $\begin{array}{l}\text { - Despite it being } \\
\text { appreciated by the participating } \\
\text { partner and project architect the } \\
\text { tool has to our knowledge never } \\
\text { been used. }\end{array}$ \\
\hline $\begin{array}{l}\text { In M5. } \\
\text { SBD }\end{array}$ & $\begin{array}{l}\text { - Approach to implement } \\
\text { their vision of "human-centred }\end{array}$ & $\begin{array}{l}\text { - } \quad \text { approach to analyse a design } \\
\text { through user journeys resulting in }\end{array}$ & $\begin{array}{l}\text { - Approach lived on in } \\
\text { other projects }\end{array}$ \\
\hline
\end{tabular}




\begin{tabular}{|c|c|c|}
\hline & $\begin{array}{l}\text { design" throughout the design } \\
\text { process. }\end{array}$ & $\begin{array}{l}\text { recommendations for the next steps in } \\
\text { the design process (Van der Linden et } \\
\text { al., 2019). } \\
\text { - fostering participants' } \\
\text { empathy with people under very } \\
\text { different circumstances and engage } \\
\text { them to apply insights gained into the } \\
\text { diversity of possible users as a source of } \\
\text { inspiration for the design (Van der } \\
\text { Linden et al., 2019). }\end{array}$ \\
\hline
\end{tabular}

Table 3. Summary of the findings

\section{What do participating organisations/firms expect?}

What healthcare and design professionals would like to gain from the interaction with the researchers turned out to differ considerably between the actors involved. Whereas we had expected healthcare organisations to be interested most in methods to gain insight into patients' experience, they appeared to be more interested in ready-to-use information about this experience. Designers, on the other hand, valued broad and nuanced information, giving them the opportunity to apply it to a concrete design. As observed in previous research (Annemans et al., 2017a, 2014), what they longed for were methods or guidance to obtain this information.

\section{What can research offer?}

In line with the aim of the program funding the knowledge-transfer project, each module started from available, substantive and/or methodological insights from completed research projects. Through the approaches adopted in the modules, the participating healthcare organisations and architecture firms gained insight into the topic they put forward, but at the same time also became more attentive for context specificities and diverging perspectives. This lay the foundation for improved (or at least new) ways of communicating. 
Insight

The offered knowledge could be based on literature reviewed in a completed research project, empirical material, or an approach made available during the workshops. The insights gained were of various kinds - into patient experience (in general or in relation to a specific healthcare context), into theoretical concepts, into an approach to deal with a challenge in the future, or a combination of these. Insight into how built space plays out in how care is experienced provided the participants of healthcare organisations with a better understanding not only of the building, but also of their own organisation and how it is lived and perceived by various users. It teaches them about their way of working and interacting. When the knowledge exchanged had a substantive character, it was used depending on the phase in the design process - to anticipate the effect of certain (design) decisions, as a source of inspiration for ongoing or future designs, or as a basis to assess design proposals or realised buildings. Methodological knowledge was exchanged both explicitly and implicitly. In the two modules with designers, we specifically developed techniques to bring across insight into patient experience which they could use independently from the workshops guided by the researchers.

Sometimes substantive research was conducted as part of a module (M2, M3), sometimes the module allowed participants to produce knowledge themselves (M5). The level of involvement in knowledge production varied significantly between organisations. Some left it completely to the researchers to collect and analyse data and later share the findings with them (M3), others had at least someone present during the data collections- and contributed to it (M2). 


\section{Increased attentiveness}

Shedding light on patient experience resulted in more attentiveness to the differences between and specificity of people's experiences. The exposure to patients' experience can take various forms, ranging from relying on completed research outcomes based on patient involvement (M1, M5) to direct engagement with (former) patients and/or staff and/or relatives (M2, M3). Becoming aware of how little they knew about others' perspective made participants realise that this was also the case for their colleagues' perspectives (M1).

\section{Improved communication}

In the module on using literature in an architecture firm supporting communication within the firm was demanded explicitly as an outcome of the interaction. Yet, also in other modules the adopted approach resulted in new ways of communicating. The workshop approach brought together people who never met before (M1, M5), allowed them to directly explicate concerns and motivate decisions.

As the knowledge-transfer project also sought a way to communicate insight into patient experience to a broader audience, the user-group suggested to set up the intended online platform in collaboration with the regional agency that subsidizes healthcare buildings. Whereas the funding agency advised as end product of the project to make experiential knowledge accessible on-line, in dialogue with the user-group we decided to set up a website as a network community, bringing together researchers, healthcare organisations and designers of healthcare products, services, or buildings. The modules are presented as examples of good 
practice on how insight into patient experience can be applied in healthcare building design.

\section{Impact}

Assessing the knowledge-transfer project's impact is difficult without insight into what is going on in the participating organisations on a daily basis. Still, we identified two directions that could be valuable. (1) Impact can be derived from further use and development of insights gained through the interactions in the modules. As the client in M5 put it, "let's see if [the participating designers] come up with it themselves in the future." This can be shown through a novel thread of thought (M1) or a prolonged mind-set and behaviour change (M5) in the respective organisations. (2) Impact is also confirmed by monetary investments (M1) or follow-up projects (M1, M3).

We found a significant contrast between how impact is assessed by the funding agency and its assessment by the participating healthcare organisations and architecture firms. The application form provided by the funding agency focused on economic added value expressed in quantitative evaluation parameters. While listed KPI's did not seem to bother the participating organisations, they somehow steered how the researchers set up the user-group meetings and public events. The focus on estimating financial impact in the application form was not reflected in the response of the participating organisations and firms. Only one (M1) mentioned an explicit (limited) investment based on the interaction. However, all of them mentioned that they valued the obtained insights, resulting attentiveness and improved communication just as much. 


\section{Discussion}

We aimed to gain a nuanced understanding of what knowledge exchange in a combined inter- and transdisciplinary context like healthcare building design means for various actors involved. Here we discuss the insights gained by retrospectively analysing a knowledge-transfer project in relation to the notion of productive interactions (Spaapen \& van Drooge, 2011).

\section{Interactions}

First and foremost, it became clear that speaking of knowledge transfer in a project were researchers and practitioners collaborate so closely to develop and produce "knowledge", does not do justice to their common effort. Therefore, it seems more accurate to redefine what is analysed here as exchange between actors (researchers and stakeholders). In theory, there are the ones offering "knowledge", i.e. the researchers; those receiving it, i.e. the research users; and those defining the conditions, i.e. the funding agency. As Lemay and Sa (2014) argue, both researchers and practitioners can have various profiles, showing more complex forms of research use than a one-way interaction between them. At the receiving side we find a broad group of healthcare professionals (from hospital board members to supporting staff) and (interior) architects, each with their own wishes and needs regarding insight into patient experience offered throughout the design process. At the offering side, outcomes from previous research were always offered by researchers, yet, it was not only them who (had) conducted research. The approaches of the modules often facilitated engaging practitioners in the research to obtain a more sustainable result. Because of the continuously shifting roles (Pentland et al., 2011), research and practice should be considered rather as a 
continuum in which both researchers and practitioners take up more or less of a research- or design-oriented task. The twofold profile of the "practice side", healthcare organisations and architecture firms, results in a triad, researcherhealthcare professional-designer, with most frequently two parties interacting with each other in order for one of them to engage with the third (Figure 2).

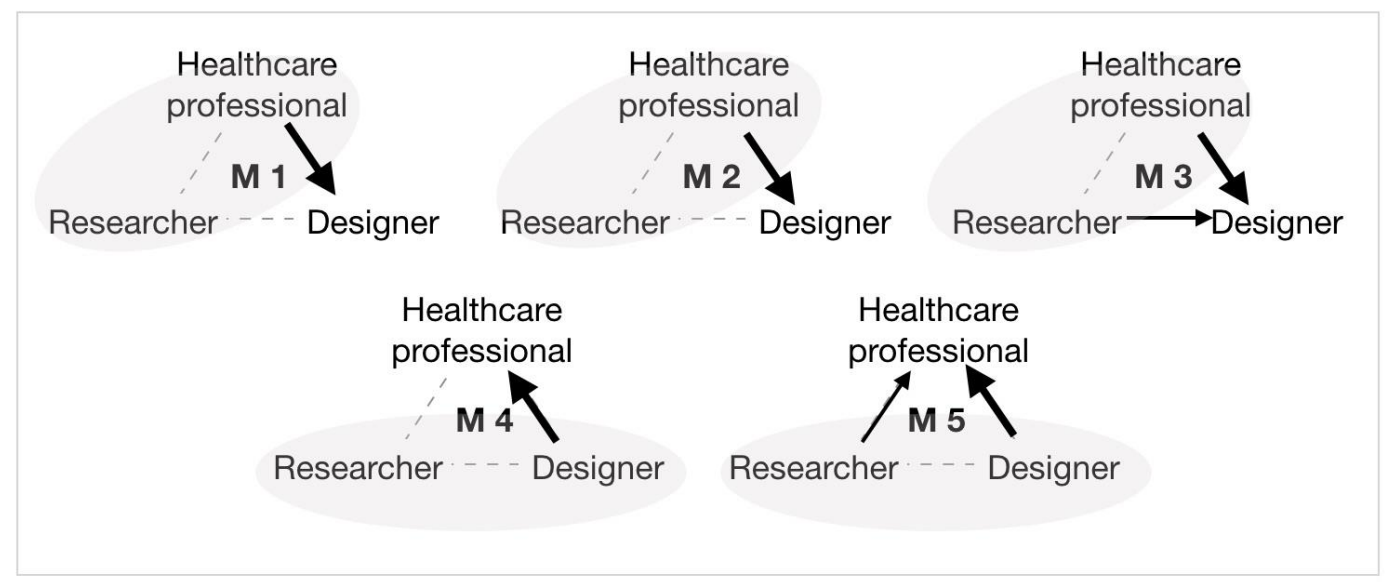

Figure 2. Triad involved in knowledge exchange with two actors interacting with each other (light grey area) in order to inform the third (arrows)

The role of the funding agency as a stakeholder in the exchange is of a different order. As our interaction with them was limited to a few face-to-face and written encounters during the project's application and defence, the funding agency is not considered an active partner during the project. This does not mean that its role should be underestimated, however. Especially with regard to what knowledge is offered and how it is valued, it has a steering role.

\section{Knowledge}

As stated by Spaapen and van Drooge (2011), knowledge that is produced and valued in the exchange between researchers and research users should be scientifically robust and socially relevant. Each party mentioned above plays its own role in this production and appreciation. Whereas in theory no new 
substantive knowledge should have been generated in the project, in reality this appeared sometimes to be necessary to achieve a fruitful collaboration with the participating healthcare organisations and architecture firms. What is exchanged, how this is approached, and which impact is pursued are steered by the researchers. This is highly influenced by what the researchers consider most relevant to be achieved, balancing between the funding agency's requirements and the participating organisations' expectations. The initial aim of the project as defined by the researchers and approved by the funding agency can align with -or substantially divert from- the goals of the participating organisations and firms.

\section{Mediation of the interactions}

The funding agency planted the seed for the knowledge exchange through its aim and requirements regarding user-group and KPI's. This triggered the user-group to suggest collaboration with the regional governmental agency that subsidizes healthcare buildings. Eventually an on-line platform aiming at knowledge sharing was launched during the project's closing event.

The tracks that mediated the exchange are diverse, varying from events explicitly organised for this purpose to more implicit, module-specific modes like workshops, presentations, or written documents. They can be based on a research publication and passed on in a one-on-one conversation between researcher and practitioner, but just as well on direct or indirect interaction with end-users (M1, M2, M3), or working on a design (M5). Overall, participants highly valued not only what was exchanged, but also how the exchange was approached. It was exactly this approach that allowed participants to communicate differently than before, with people from within or outside their own organisation (M1, M5), or 
provided them with new insights improving their understanding of patient experience (M1).

\section{(Societal) impact}

The impact of the knowledge-transfer project, or the productivity of the interactions, does not only concern adaptations to the design of particular healthcare buildings, but reaches beyond the building projects discussed. When research outcomes are introduced to solve a real-world problem, the extent of their impact heavily depends on the "track" followed, and the audience reached. Ideally insight into patient experience is introduced early in the design process and evolves parallel with it. Such an approach aligns with the idea to assess impact based on the process rather than on outcome only (Upton et al., 2014), at this moment however, this contrasts sharply with the technology transfer the funding agency aims for. In this respect, it would be interesting to further investigate alternative application procedures to attune the project's preparation to its later development. After the application phase we referred to the application form only when reporting the end results. Instead it could be conceived as an actual plan supporting the development, steering and evaluation of interactions throughout the project.

The purpose of the knowledge-transfer project was to support the participating healthcare organisations and architecture firms in improving the healthcare environments they were designing with regard to end-users' experience and wellbeing. Whether the outcomes will actually impact on human well-being through adaptations to the healthcare buildings, and what this impact will be, is -in line 
with Morton's (2015a) findings- difficult to predict at this point. Some hints include further investment (M1), a planned follow-up study (M3), and organisations continuing to use the offered material (M5). The potential of secondary use is even harder to assess (Upton et al., 2014), yet also here hints are starting to appear. The modules created social impact by changing the social relations between people especially within the participating healthcare organisations, but also between healthcare organisations and end-users (M1, M3) and between healthcare organisations and architecture firms (M5). Moreover, they allowed healthcare professionals and architects to gain a better understanding of end-users' experiences, which raised awareness about the divergence between their own lifeworld and the one of those they are designing for (M1, M2, M3, M5).

\section{Implications for "practice"}

Applying the concept of "productive interactions" to analyse a knowledge-transfer project allows to identify a shift from knowledge transfer to knowledge exchange, in terms of the meaning of what is exchanged (now referred to as knowledge), the role of the exchange process and the followed track, and the (societal) impact. This shift has implications for healthcare and design research and practice. Starting from the notion of exchange rather than transfer may raise awareness amongst researchers and practitioners, whether healthcare professionals or designers, about the fluidity of their roles in the process, shifting research and design tasks from one to the other depending on the phase and purpose of the process. While this insight is not new (Gibbons et al., 1994), our analysis of the knowledge-transfer project adds a stronger focus on research impact. The methods 
and techniques used in the modules result in knowledge exchange tracks that allow and facilitate fluid interactions both between different parties, and between people with different profiles from one party. For practice -c.q. in healthcare and design- this means that practitioners could consider themselves equal partners in future knowledge exchange projects, which may help to achieve research outcomes close to their needs. Such an evolution in the relationship between research and practice challenges funding agencies to evolve accordingly. In order to allow truly inter- and transdisciplinary, socially relevant research to happen, forms of funding support may be needed that allow more uncertainty in project outcomes and acknowledge the complexity of knowledge exchange.

Governmental agencies can take an active role in guarding and further developing long-term impact.

\section{Conclusion}

Analysing a knowledge transfer-project retrospectively offered a broad view on what knowledge transfer in an inter- and transdisciplinary context, like healthcare building design, means for various actors involved. Additionally, it drew attention to the fluidity of the roles of researchers and practitioners.

Practitioners, in healthcare organisations and architecture firms, consider knowledge valuable when it allows them to make a change for the better in the built environment or the design process thereof. For them the exchange process needs to add to this improvement regardless of who - they themselves or the researchers - actually formulates concrete recommendations. From a research perspective knowledge exchange is more about exchanging scientifically substantiated ideas or concepts that can be applied to a concrete issue, but have 
relevance for practice beyond the participating healthcare organisation or architecture firm. The funding program, with its original idea of technology transfer rather than knowledge exchange, ultimately strives for directly applicable knowledge that can be transferred in a one-size-fits-all model.

Introducing the concept of "productive interactions" allowed to situate the divergent views on knowledge exchange and to take a step back in order to also assess the process in terms of (societal) impact. As such the relations between the different actors are taken into account, illustrating how interdisciplinary research is used to solve problems of non-academic stakeholders, not just for them, but with them (type 2 transdisciplinarity). Moreover, given the concept's aim to explicate a way to assess societal impact, discussing the knowledge-transfer project from this perspective allowed us to extend the focus on knowledge and how it is transferred, or rather exchanged, towards what implications or impact this could have and how these can be assessed.

It would be interesting for future research to explore how productive interactions with an eye to improving well-being and social relations could be better supported from the application phase on. Funding agencies will have an important role to play in this. As research funding is increasingly based on potential impact, future realisations of productive interactions could be supported by evaluating knowledge-transfer projects in terms of process and outcomes, thus acknowledging the shifting roles of researchers and practitioners, and the potential to improve well-being and social relations through research. 


\section{Acknowledgments}

Special thanks to the study's participants, members of the user-group, colleagues who participated in de modules, and everyone else who contributed to this study.

\section{Funding}

This work was supported by the Flanders Innovation \& Entrepreneurship [grant number FIS TETRA 140570].

\section{Declaration of interest statement}

The authors do not have any conflicts of interest to declare. 


\section{References}

Annemans, M., Stam, L., Coenen, J., \& Heylighen, A. (2017a). Informing hospital design through research on patient experience. The Design Journal, 20(sup1), S2389S2396. https://doi.org/10.1080/14606925.2017.1352753

Annemans, M., Stam, L., Coenen, J., \& Heylighen, A. (2017b). How can research on patient experience inform hospital design? A case study on improving wayfinding. $3 r d$ international conference on architecture, research, care and health, 345-357.

Annemans, M., Van Audenhove, C., Vermolen, H., \& Heylighen, A. (2014). How to Introduce Experiential User Data: The Use of Information in Architects' Design Process. Design's Big Debates. The Design Research Society's 2014 conference, 16261637.

Belcher, B. M., Rasmussen, K. E., Kemshaw, M. R., \& Zornes, D. A. (2016). Defining and assessing research quality in a transdisciplinary context. Research Evaluation, 25(1), 1-17. https://doi.org/10.1093/reseval/rvv025

Cruz Rivera, S., Kyte, D. G., Aiyegbusi, O. L., Keeley, T. J., \& Calvert, M. J. (2017). Assessing the impact of healthcare research: A systematic review of methodological frameworks. PLOS Medicine, 14(8), e1002370.

https://doi.org/10.1371/journal.pmed.1002370

Fazey, I., Bunse, L., Msika, J., Pinke, M., Preedy, K., Evely, A. C., Lambert, E., Hastings, E., Morris, S., \& Reed, M. S. (2014). Evaluating knowledge exchange in interdisciplinary and multi-stakeholder research. Global Environmental Change, 25, 204-220. https://doi.org/10.1016/j.gloenvcha.2013.12.012

Fazey, I., Evely, A. C., Reed, M. S., Stringer, L. C., Kruijsen, J., White, P. C. L., Newsham, A., Jin, L., Cortazzi, M., Phillipson, J., Blackstock, K., Entwistle, N., Sheate, W., Armstrong, F., Blackmore, C., Fazey, J., Ingram, J., Gregson, J., Lowe, P., ... 
Trevitt, C. (2013). Knowledge exchange: A review and research agenda for environmental management. Environmental Conservation, 40(1), 19-36. https://doi.org/10.1017/S037689291200029X

Fereday, J., \& Muir-Cochrane, E. (2006). Demonstrating Rigor Using Thematic Analysis: A Hybrid Approach of Inductive and Deductive Coding and Theme Development. International Journal of Qualitative Methods, 5(1), 80-92.

Gibbons, M., Limoges, C., \& Nowotny. (1994). The new production of knowledge: The dynamics of science and research in contemporary societies. SAGE Publications.

Kampen, J. K., \& Tamás, P. (2014). Should I take this seriously? A simple checklist for calling bullshit on policy supporting research. Quality \& Quantity, 48(3), 1213-1223. https://doi.org/10.1007/s11135-013-9830-8

Kirkeby, I. M. (2009). Knowledge in the making. Architectural Research Quarterly, 13(3-4), 307. https://doi.org/10.1017/S1359135510000151

Lemay, M. A., \& Sa, C. (2014). The use of academic research in public health policy and practice. Research Evaluation, 23(1), 79-88. https://doi.org/10.1093/reseval/rvt029 Morton, S. (2015a). Creating research impact: The roles of research users in interactive research mobilisation. Evidence \& Policy: A Journal of Research, Debate and Practice, 11(1), 35-55. https://doi.org/10.1332/174426514X13976529631798

Morton, S. (2015b). Progressing research impact assessment: A 'contributions' approach. Research Evaluation, 24(4), 405-419. https://doi.org/10.1093/reseval/rvv016 Penfield, T., Baker, M. J., Scoble, R., \& Wykes, M. C. (2014). Assessment, evaluations, and definitions of research impact: A review. Research Evaluation, 23(1), 21-32. https://doi.org/10.1093/reseval/rvt021

Pentland, D., Forsyth, K., Maciver, D., Walsh, M., Murray, R., Irvine, L., \& Sikora, S. (2011). Key characteristics of knowledge transfer and exchange in healthcare: 
Integrative literature review: Knowledge transfer and exchange in healthcare. Journal of Advanced Nursing, 67(7), 1408-1425. https://doi.org/10.1111/j.1365-

2648.2011.05631.x

Sachs, N. A. (2018). Here's Some Great Research! Now What? Translating Research Into Practice. HERD: Health Environments Research \& Design Journal, 11(1), 40-42. https://doi.org/10.1177/1937586718757309

Sakao, T., \& Brambila-Macias, S. A. (2018). Do we share an understanding of transdisciplinarity in environmental sustainability research? Journal of Cleaner Production, 170, 1399-1403. https://doi.org/10.1016/j.jclepro.2017.09.226

Spaapen, J., \& van Drooge, L. (2011). Introducing "productive interactions" in social impact assessment. Research Evaluation, 20(3), 211-218.

https://doi.org/10.3152/095820211X12941371876742

Stichler, J. F. (2015). Hospitals of the Future. HERD: Health Environments Research \& Design Journal, 8(3), 6-8. https://doi.org/10.1177/1937586714565602

Straus, S. E., Tetroe, J. M., \& Graham, I. D. (2011). Knowledge translation is the use of knowledge in health care decision making. Journal of Clinical Epidemiology, 64(1), 610. https://doi.org/10.1016/j.jclinepi.2009.08.016

Upton, S., Vallance, P., \& Goddard, J. (2014). From outcomes to process: Evidence for a new approach to research impact assessment. Research Evaluation, 23(4), 352-365. https://doi.org/10.1093/reseval/rvu021 van den Akker, W., Spaapen, J., \& Maes, K. (2017). Productive interactions: Societal impact of academic research in the knowledge society. https://www.leru.org/publications/productive-interactions-societal-impact-of-academicresearch-in-the-knowledge-society\# Van der Linden, V., Dong, H., \& Heylighen, A. (2019). Populating Architectural 
Design: Introducing Scenario-Based Design in Residential Care Projects. International Journal of Design, 13(1), 21-36.

Zhang, Y., Tzortzopoulos, P., \& Kagioglou, M. (2019). Healing built-environment effects on health outcomes: Environment-occupant-health framework. Building Research \& Information, 47(6), 747-766.

https://doi.org/10.1080/09613218.2017.1411130 